\title{
一軸偏心した非剛床木質構造の動的特性および地震応答に関する基礎的研究 A BASIC STUDY ON DYNAMIC PROPERTY AND SEISMIC RESPONSE OF TIMBER STRUCTURE WITH FLEXIBLE FLOOR AND UNI-AXIAL STIFFNESS ECCENTRICITY
}

\author{
山崎義弘*, 笠井和彦**, 坂田弘安*** \\ Yoshihiro YAMAZAKI, Kazuhiko KASAI and Hiroyasu SAKATA
}

\begin{abstract}
Dynamic properties and seismic responses of timber structure are discussed, with focus on uni-axial stiffness eccentricity of structural walls and horizontal flexibility of floor diaphragm. The stiffness eccentricity factor $R_{e}$ defined in Japanese building standard law assumes rigid diaphragm, which can result in considerable error in estimations for torsional properties/responses of timber structures. Simplified formulations for the dynamic properties considering the diaphragm flexibility are given, and are applied to discuss seismic responses of example structures. The stiffness of horizontal diaphragm appears to affect not only the torsional response but also the translational response of the structure.
\end{abstract}

Keywords : Rigid floor, Flexible floor, Horizontal diaphragm, Torsional response, Stiffness eccentricity, Wooden house 剛床, 非剛床, 水平構面, 㧖れ応答, 剛性偏心, 木造住宅

1.はじめに

\section{1 背景}

木造住宅では建築計画上の理由から耐力壁が偏在し、大きな剛性 偏心が生じることを避け難いケースが数多く存在する ${ }^{1)}$ 。のため、 地震時据れ応答を予測し、これを耐震設計法に反映させることは不 可欠であり、振動台実験による検証なども盛んに行われている ${ }^{2,3)}$ 。 また、建物に据れが生じても水平構面がその形状を維持すれば、直 交壁などが据れに対して抵抗できるのに対し、水平構面の剛性が不 十分な構造では、据れに対する各壁の抵抗力を伝達できず、水平構 面がせん断変形するため、据れに対して脆弱になることが知られて いる。特に既存の古い軸組工法住宅や伝統構法による木造住宅では、 上述の影響が懸念され、多くの研究報告がなされている ${ }^{2,4-6)}$ 。

現行の耐震設計法で用いられる偏心率は、剛床仮定に基づく建物 の特性值から求められるため、例えば軸組工法住宅の設計において、 品確法の壁量計算法や許容応力度計算法では、水平構面に対して必

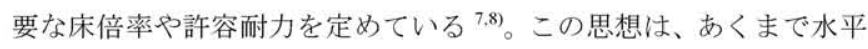
構面の先行破壊を防ぎ、耐力壁が終局耐力まで性能を発揮すること を担保するための規定と考えられる。阿川ら ${ }^{2}$ 芯実験的に示したよ うな、水平構面の変形による建物の固有周期の伸び、変形モードの 著しい変化など、建物の動的な性状の変化という観点からも、水平 構面に要求される性能を考えてみる必要があるだろう。現行の規準 に基づき設計された木造住宅は、多くの実験などにより、その耐震 安全性が検証されている中で、水平構面の剛性が建物の耐震性能に 及ぼす影響については、未解明な点が残されていると考えられる。 これまでに水平構面の剛性を考慮した新たな耐震設計法の提案が
試みられているが、地震力を質量中心に作用する静的な外力として 扱ったもの ${ }^{9-11)}$, 立体骨組の解析結果に基づく経験則的な評価法

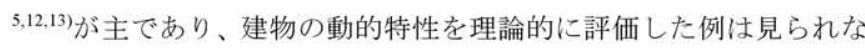
い。据れ振動問題に関して、古くは志賀やChopra らが理論を確立し てきたが ${ }^{14,15)}$, これまで非剛床を対象とした厳密な理論は無い。

そこで本論では、剛床仮定が成立しない「非剛床構造」の複雑な動 的挙動を理論に基づいて精確に把握することに主眼を置き、その基 礎的な検討として、水平構面全体が一様にせん断変形しながら据れ る変形モードを仮定する。当然、現実にはさらに複雑な変形モード となる可能性があり、上述の仮定の適用性は限られるが、まずは剛 床仮定が成立しない上で、なるべく少ない自由度での検討を行う。

\section{2 本論文の目的と構成}

本論は、据れを伴う建物の地震応答に水平構面の剛性が与える影 響を把握することを目的として、まずは基本となる線形構造を対象 とした動的特性の評価法を考案し、これに基づき地震応答の傾向を パラメトリックに分析する。また、既往の手法とは異なる本論の理 論に基づき、剛床仮定が成立しうるクライテリアを探ってみること も、意義があるものと考える。論文の構成は以下の通りである。

2 章では、本論で考慮する構造モデルの前提条件を述べ、既往の 評価法との比較を行う。

3 章では、まず剛床仮定に基づく運動方程式を導出し、これに水 平構面のせん断変形という新たな自由度を追加し、非剛床構造へ拡 張する。また、その過程で発生する据れの支配特性值も定義する。

4 章では、想定する構造モデルから㨭れの支配特性値の想定範囲 を調へ、、水平構面剛性とシステムの動的特性の関係を示す。また、
* 東京工業大学大学院

日本学術振興会特別研究員 DC·修士(工学)

** 東京工業大学建築物理研究センター 教授. Ph. D.

*** 東京工業大学建築物理研究センター 准教授. 工博

\section{JSPS Research Fellow, Tokyo Institute of Technology, M. Eng.}

Prof., Struct. Eng. Res. Center, Tokyo Institute of Technology, Ph. D. Assoc. Prof., Struct. Eng. Res. Center, Tokyo Institute of Technology, Dr. Eng. 
現行の耐震設計法で用いられる偏心率との関係についても論ずる。

5 章では、地震入力を応答スペクトルで定義し、システムの地震 最大応答を評価することで、水平構面剛性とシステムの最大応答の 関係を示す。

\section{2. 前提条件}

\section{1 本論で考慮する $1 \times 1$ スパンの構造モデル}

本論では図 1 (左)に示す 1 層 $1 \times 1$ スパンの耐力壁構造を考虑する。 耐力壁は外周部のみに存在し、 $x$ 方向の二つの構面の剛性が不均等 であるため、 $y$ 方向に剛性中心が偏心している。また、水平構面 (こ こでは 2 階の床面を指す) はある程度の柔性を有するものとする。 耐力壁や水平構面などの質量は、建物平面内に均等に分布している と考え、全質量を水平構面内で均して扱う。

図 2 は慣性力と耐力壁の抵抗力の釣り合いと、これらによる水平 構面の応答変位分布を表している。 $x$ 方向にのみ地震入力を与えた 場合、建物に生じる慣性力は、剛床かつ無偏心時に限って一様な分 布となるが(図 2(a)), 非剛床時や剛性偏心が生じた場合には、複雑な 慣性力分布となる(図 2(b), (c))。本論では耐力壁の抵抗力が水平構面 の外周部に作用し、さらに比較的小規模の建物を対象とすることで、 水平構面は平行四辺形に変形すると仮定する。よって、図 2(c)の場 合の慣性力分布は、台形あるいは三角形で表され、この外力分布に 対する応答を求める。なお、水平構面には吹き抜けなどは無く、一 様なせん断剛性を有するものとする。

\section{2 既往の評価法との比較}

非剛床構造の据れ応答を対象とした既往の評価法・解析法につい てここで詳述し、後述する本手法との違いを示す。

水平構面に㨝れやせん断変形が生じる建物は、慣性力の分布形状 が未知であるため(図 2), 振動モデルによる時刻歴解析が唯一の解 析手法となる。このことから、非剛床構造の㧖れ応答の解析では、

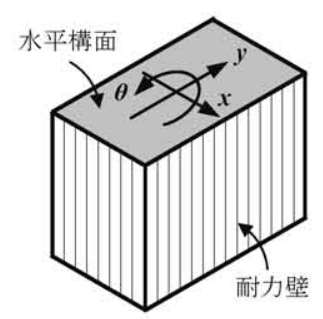

図 1 本論で考慮する 1 層 $1 \times 1$ スパン耐力壁構造

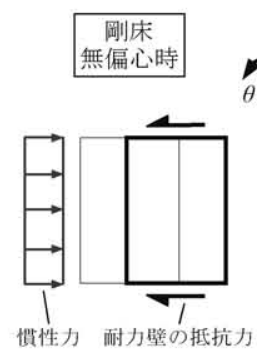

(a) 並進

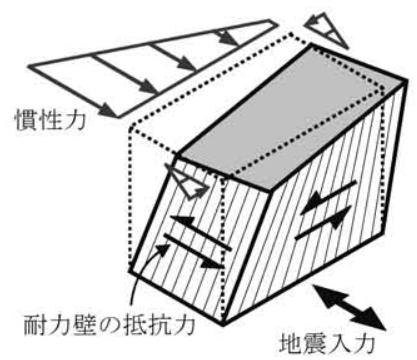

地震入
図 2 水平構面に加わる慣性力 - 耐力壁の抵抗力の釣り合いと これらによる水平構面の応答変位分布
図 3 に示すように水平構面をせん断パネルやブレースで置換したモ

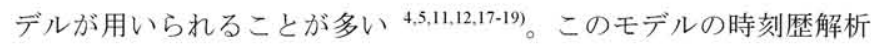
は実建物の地震応答の再現として信頼性が高いものと考えられるが、 自由度が高くなるほど、水平構面の剛性と建物の地震応答の関係は 定性的にしか把握できなくなる。

1 層 $1 \times 1$ スパンの構造では、静的な力の釣り合いと、水平構面の 変形も含めた適合条件から、偏心率や㨭れ補正係数の導出が試みら れているが 10,11), 前述のごとく静的な計算法では慣性力分布の変動 を考虑しないため(図 2), その精度面から適用範囲が限られる。

これらに対して本論の手法は、図 3(b)のような $1 \times 1$ スパンの振動 解析モデルの自由度を縮約し、建物の地震応答は縮約した運動方程 式を解くことで得られるようになる。このように最小限の自由度を 与えた簡便な構造モデルの運動方程式に縮約することの利点は、そ の導出過程で非剛床構造の特性を表す数種の構造パラメータも導出 され、これらとシステムの動的特性との関係が明確になることにあ る。多スパンの場合には、より多くの自由度と構造パラメータが必 要であり、煩雑な理論となってしまうため、まずは $1 \times 1$ スパンでの 理論の構築を行う。なお、後述する本論の手法は、図 3(b)に示す振 動解析モデルの時刻歷解析と等しい解が得られることを述べておく。

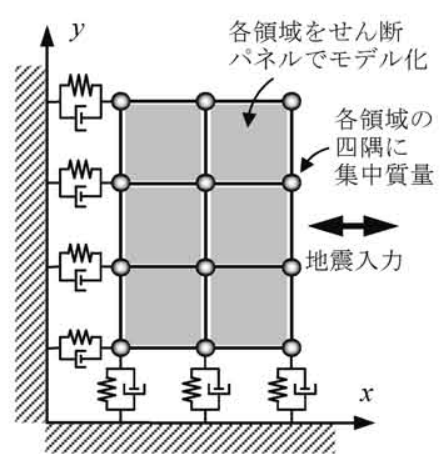

(a) 多スパンの場合

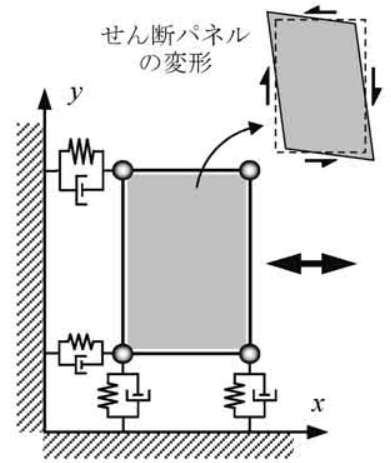

(b) $1 \times 1$ スパンの場合
図 3 非剛床構造の据れを考慮した振動解析モデルの例

\section{3. 運動方程式}

\section{1 剛床の場合}

図 4 は本論で考慮する構造モデルを示し、その変形モードを図 5 のように考える。本節では、まず剛床仮定に基づく定式化を述べ ${ }^{16)}$, 水平構面のせん断変形角 $\gamma=0$ とする。

剛床に対して $x, y$ 各方向に有効な剛性要素および粘性要素を接続 し、 $x$ 方向の地震動入力を与える。 $x$ 方向に有効な剛性要素と粘性 要素それぞれで、 $i$ 番目の要素の剛性、粘性を $k_{x i}, c_{x i}$ とし、質量中 心 c. m. (center of mass) からの距離を $y_{i}, y_{i}^{\prime}$ とする。また、 $y$ 方向に 有効な要素では同様に $k_{y i}, c_{y i}$ とし、質量中心からの距離を $x_{i}, x_{i}^{\prime}$ と する。なお、原点は質量中心に設定する。以上に基づき、

$$
\begin{array}{ll}
K_{x}=\sum_{i} k_{x i}, & K_{\theta}=\sum_{i}\left(k_{x i} y_{i}{ }^{2}+k_{y i} x_{i}^{2}\right), e_{y}=\sum_{i} k_{x i} y_{i} / K_{x} \\
C_{x}=\sum_{i} c_{x i}, C_{\theta}=\sum_{i}\left(c_{x i} y_{i}^{\prime 2}+c_{y i} x_{i}^{2}\right), e_{y}^{\prime}=\sum_{i} c_{x i} y_{i}^{\prime} / C_{x}
\end{array}
$$

式(1)において、 $K_{x}, K_{\theta}=x$ 方向剛性総和、質量中心回りの㨭れ剛性、 そして $e_{y}=$ 剛性偏心距離、つまり質量中心 $c . m$. から $x$ 方向剛性の剛 性中心 c.s. (center of stiffness) までの位置ベクトルの長さであり、べ 


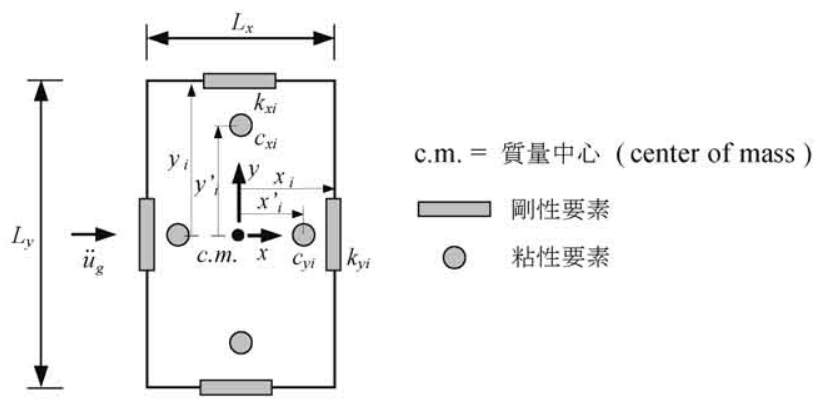

図 4 構造モデルにおける剛性要素と粘性要素の位置の定義

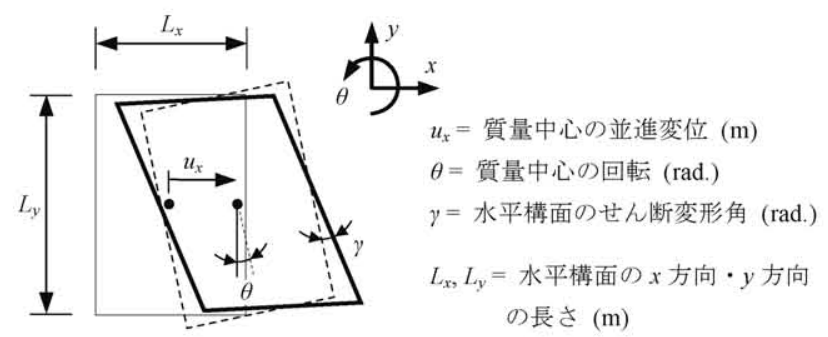

図 5 構造モデルの変形モード

クトルが $y$ 方向正の場合 $e_{y}>0$ となる。また、式(2)では、 $C_{x}, C_{\theta}=x$ 方向粘性総和、質量中心回りの据れ粘性と呼び、 $e_{y}^{\prime}=$ 粘性偏心距離、 つまり質量中心から $x$ 方向粘性の粘性中心 c.d. (center of damping) までの位置ベクトルの長さであり、 $y$ 方向正の場合 $e_{y}^{\prime}>0$ とする。

質量中心に作用する $x$ 方向の力とモーメントの釣り合いから、

$$
\begin{aligned}
{\left[\begin{array}{cc}
m & 0 \\
0 & I
\end{array}\right]\left\{\begin{array}{c}
\ddot{u}_{x} \\
\ddot{\theta}
\end{array}\right\} } & +\left[\begin{array}{cc}
C_{x} & -C_{x} e_{y}^{\prime} \\
-C_{x} e_{y}^{\prime} & C_{\theta}
\end{array}\right]\left\{\begin{array}{c}
\dot{u}_{x} \\
\dot{\theta}
\end{array}\right\} \\
& +\left[\begin{array}{cc}
K_{x} & -K_{x} e_{y} \\
-K_{x} e_{y} & K_{\theta}
\end{array}\right]\left\{\begin{array}{c}
u_{x} \\
\theta
\end{array}\right\}=-\left[\begin{array}{cc}
m & 0 \\
0 & I
\end{array}\right]\left\{\begin{array}{l}
1 \\
0
\end{array}\right\} \ddot{u}_{g}
\end{aligned}
$$

となる。ここに、 $m, I=$ 水平構面の質量と回転慣性、 $\ddot{u}_{g}=x$ 方向地 動加速度、 $u_{x}, \theta=$ 質量中心の $x$ 方向変位と回転( $\left.\mathrm{rad}.\right)$ である。

さらに、式(1),(2)から以下のパラメータを定義する。

$$
\begin{array}{lll}
\omega_{x}=\sqrt{K_{x} / m}, & \omega_{\theta}=\sqrt{K_{\theta} / I}, & \bar{e}_{y}=e_{y} / r_{m} \\
h_{x}=C_{x} /\left(2 m \omega_{x}\right), & h_{\theta}=C_{\theta} /\left(2 I \omega_{\theta}\right), & \bar{e}_{y}^{\prime}=e_{y}^{\prime} / r_{m}
\end{array}
$$

ここに、 $\omega_{x}, h_{x}=x$ 方向変位のみが生じるよう回転を拘束したモデル の固有円振動数、減衰定数である。同様に、 $\omega_{\theta}, h_{\theta}=$ 回転のみが生 じるよう $x$ 方向変位を拘束した場合の固有円振動数、減衰定数であ る。また、 $\bar{e}_{y}, \bar{e}_{y}^{\prime}=$ 剛性偏心比、粘性偏心比と定義する。 $r_{m}$ は質 量回転半径であり、これを用いて、

$$
\Delta u_{x}=r_{m} \theta, \quad r_{m}=\sqrt{I / m}
$$

という変換を考える。 $\Delta u_{x}$ は、質量中心から距離 $r_{m}$ にある点の、質 量中心に対する $x$ 方向相対変位であり、回転 $\theta$ によって生じる。こ れらを用いて式(3)を書き換える。すなわち、

$$
\begin{aligned}
& \mathbf{m} \ddot{\mathbf{u}}+\mathbf{c} \dot{\mathbf{u}}+\mathbf{k} \mathbf{u}=-\mathbf{m}\{\mathbf{1}\} \ddot{u}_{g} \\
& \mathbf{m}=\left[\begin{array}{ll}
1 & 0 \\
0 & 1
\end{array}\right], \quad \mathbf{u}=\left\{\begin{array}{c}
u_{x} \\
\Delta u_{x}
\end{array}\right\}, \quad\{\mathbf{1}\}=\left\{\begin{array}{l}
1 \\
0
\end{array}\right\} \\
& \mathbf{c}=2 h_{x} \omega_{x}\left[\begin{array}{cc}
1 & -\bar{e}_{y}^{\prime} \\
-\bar{e}_{y}^{\prime} & \frac{h_{\theta}}{h_{x}} \frac{\omega_{\theta}}{\omega_{x}}
\end{array}\right], \quad \mathbf{k}=\omega_{x}^{2}\left[\begin{array}{cc}
1 & -\bar{e}_{y} \\
-\bar{e}_{y} & \frac{\omega_{\theta}^{2}}{\omega_{x}^{2}}
\end{array}\right]
\end{aligned}
$$

式(7)が質量マトリクスで基準化した剛床時の運動方程式である。ま た、式(8)に現れる $\omega_{\theta} / \omega_{x}, \bar{e}_{y}, h_{\theta} / h_{x}, \bar{e}_{y}^{\prime}$ の合計 4 種のパラメータを 「据れの支配特性值」之呼ぶ ${ }^{16)}$ 。

\section{2 非剛床の場合}

剛床時は $u_{x}$ と $\theta$ を変数とした 2 自由度系となったが、非剛床では これに水平構面のせん断変形角 $\gamma$ を追加し、3 自由度系となる(図 5)。 ここで言うせん断変形角とは、いわゆるせん断パネルのひずみテン ソル成分としてのせん断ひずみを差す。

図 6(a)のように、 $x$ 方向・ $y$ 方向の各力によるモーメントは、水平 構面を介して釣り合う。これを図 6(b)のように水平構面の端部に作 用する集中荷重 $Q_{x}, Q_{y}$ によるモーメントとして置き換えると、

$$
Q_{x} L_{y}=-M^{(x)}-I^{(x)}(\ddot{\theta}+\ddot{\gamma}) \quad, \quad Q_{y} L_{x}=M^{(v)}+I^{(v)}(\ddot{\theta}-\ddot{\gamma})
$$

質量中心回りのモーメントの釣り合いは次式となる。

$$
\begin{aligned}
& Q_{x} L_{y}=Q_{y} L_{x} \\
& M^{(x)}+M^{(y)}+I \ddot{\theta}+\left(I^{(x)}-I^{(y)}\right) \ddot{\gamma}=0
\end{aligned}
$$

ここで、 $M^{(x)}, M^{(y)}=x$ 方向・ $y$ 方向の壁による質量中心回りの抵抗モ 一メントである。質量中心から $x \cdot y$ 方向に $x_{m j}, y_{m j}$ の距離にある質量 $m_{j}$ の微小領域を考え(図 7), これに生じる慣性力によるモーメント の積分值から、回転慣性 $I$ と $I^{(x)}, I^{(y)}$ が以下のように得られる。

$$
\begin{array}{rlrl}
I & =\sum_{j} m_{j}\left(x_{m j}^{2}+y_{m j}^{2}\right) \\
& =I^{(v)}+I^{(x)}\left(=\frac{m}{12}\left(L_{x}^{2}+L_{y}^{2}\right)\right) \quad & & m=\sum_{j} m_{j} \\
I^{(x)} & =\sum_{j} m_{j} y_{m j}^{2}\left(=\frac{m L_{y}^{2}}{12}\right), & I^{(v)}=\sum_{j} m_{j} x_{m j}^{2}\left(=\frac{m L_{x}^{2}}{12}\right)
\end{array}
$$

式(11a), (11c), (11d)の右端に示した括弧付きの項は、均等質量分布の 場合であり、一般には各質量と質量中心からの距離の二乗の積の総 和として求める。 $I^{(x)}, I^{(v)}($ 式(11c), (11d)) は図 7(b)のように水平構面 にせん断変形角 $\gamma$ が生じたときの慣性モーメント $\left(I^{(x)}-I^{(v)}\right) \ddot{i}$ (式 (10b)左辺の第 4 項)に関する回転慣性を表す。

ここで、便宜上、せん断弾性係数 $G$, 厚さ $t$ の床版が一様に分布 している水平構面を扱うことにする。この仮定を木質構造にも適用 することの妥当性は、付録 $\mathrm{A}$, 付録 $\mathrm{B}$ で検証する。また、水平構面 は $x$ 方向・ $y$ 方向の辺長がそれぞれ $L_{x}, L_{y}$ である長方形とする(図 5)。

図 6(b)に示す応力状態の仮定から、水平構面内のせん断力分布は 一様になる。また、図 6(b)に示す状態を考えると、水平構面に生じ る工学的せん断ひずみは $2 \gamma$ であることから、水平構面のせん断力に 関する構成則は、

$$
Q_{x} /\left(t L_{x}\right)=2 G \gamma \quad, \quad Q_{y} /\left(t L_{y}\right)=2 G \gamma
$$
となる。これらの左辺を、式(9)のごとくモーメントの次元で表せば、

$$
\begin{aligned}
& Q_{x} L_{y}=2 G V \gamma \quad, \quad Q_{y} L_{x}=2 G V \gamma \\
& V=t L_{x} L_{y}
\end{aligned}
$$

$V$ は水平構面の体積を表す。式(13)から分かるように、水平構面の せん断変形角 $\gamma$ は、水平構面を介して釣り合うモーメントに比例し、 その比例係数は $2 G V$ となる。

式(13a)に式(13b)の両辺をそれぞれ加え、式(9)を代入すれば、 


$$
M^{(x)}-M^{(y)}+\left(I^{(x)}-I^{(y)}\right) \ddot{\theta}+I \ddot{\gamma}+4 G V \gamma=0
$$
$M^{(x)}, M^{(v)}$ は、式(1),(2)のパラメータを用いて次のように表される。

$$
\begin{aligned}
& M^{(x)}=-C_{x} e_{y}^{\prime} \dot{u}_{x}+C_{\theta}^{(x)}(\dot{\theta}+\dot{\gamma})+-K_{x} e_{y} u_{x}+K_{\theta}^{(x)}(\theta+\gamma) \\
& M^{(y)}=C_{\theta}^{(v)}(\dot{\theta}-\dot{\gamma})+K_{\theta}^{(y)}(\theta-\gamma)
\end{aligned}
$$

これより、非剛床の場合の運動方程式を次のように得る。

$$
\begin{aligned}
& {\left[\begin{array}{ccc}
m & 0 & 0 \\
0 & I & I^{(x)}-I^{(y)} \\
0 & I^{(x)}-I^{(y)} & I
\end{array}\right]\left\{\begin{array}{c}
\ddot{u}_{x} \\
\ddot{\theta} \\
\ddot{\gamma}
\end{array}\right\}+\left[\begin{array}{ccc}
C_{x} & -C_{x} e_{y}{ }^{\prime} & -C_{x} e_{y}{ }^{\prime} \\
-C_{x} e_{y}{ }^{\prime} & C_{\theta} & C_{\theta}^{(x)}-C_{\theta}^{(y)} \\
-C_{x} e_{y^{\prime}} & C_{\theta}^{(x)}-C_{\theta}^{(y)} & C_{\theta}
\end{array}\right]\left\{\begin{array}{c}
\dot{u}_{x} \\
\dot{\theta} \\
\dot{\gamma}
\end{array}\right\}} \\
& +\left[\begin{array}{ccc}
K_{x} & -K_{x} e_{y} & -K_{x} e_{y} \\
-K_{x} e_{y} & K_{\theta} & K_{\theta}^{(x)}-K_{\theta}^{(v)} \\
-K_{x} e_{y} & K_{\theta}^{(x)}-K_{\theta}^{(y)} & K_{\theta}+4 G V
\end{array}\right]\left\{\begin{array}{c}
u_{x} \\
\theta \\
\gamma
\end{array}\right\}=-\left[\begin{array}{ccc}
m & 0 & 0 \\
0 & I & I^{(x)}-I^{(v)} \\
0 & I^{(x)}-I^{(v)} & I
\end{array}\right]\left[\begin{array}{l}
1 \\
0 \\
0
\end{array}\right) \ddot{u}_{g}
\end{aligned}
$$

$$
\text { ここに、 }
$$

$$
\begin{array}{lll}
K_{\theta}^{(x)}=\sum_{i} k_{x i} y_{i}{ }^{2}, & K_{\theta}^{(v)}=\sum_{i} k_{y i} x_{i}{ }^{2}, & K_{\theta}=K_{\theta}^{(x)}+K_{\theta}^{(y)} \\
C_{\theta}^{(x)}=\sum_{i} c_{x i} y_{i}{ }^{2}, & C_{\theta}^{(v)}=\sum_{i} c_{y i} x_{i}^{\prime 2}, & C_{\theta}=C_{\theta}^{(x)}+C_{\theta}^{(v)}
\end{array}
$$

式(18a,b)は、それぞれ $x$ 方向・ $y$ 方向の壁による据れ剛性への寄与 分、式(19a,b)は $x$ 方向・ $y$ 方向の壁による据れ粘性への寄与分であ る。式(18),(19)などから、以下のパラメータを新たに定義する。

$$
\begin{aligned}
& \cos ^{2} \psi_{x}=K_{\theta}^{(x)} / K_{\theta} \quad, \quad \sin ^{2} \psi_{x}=K_{\theta}^{(y)} / K_{\theta} \\
& \cos ^{2} \psi_{x}^{\prime}=C_{\theta}^{(x)} / C_{\theta} \quad, \quad \sin ^{2} \psi_{x}^{\prime}=C_{\theta}^{(y)} / C_{\theta} \\
& \alpha=\left(I^{(x)}-I^{(y)}\right) / I \quad, \quad \beta=\sqrt{4 G V / I}
\end{aligned}
$$

式(6a)と同様に、次のような変数変換も行う。

$$
\Delta u_{x}^{\prime}=r_{m} \gamma
$$

$\Delta u_{x}^{\prime}$ は、非剛床の場合に水平構面のせん断変形角 $\gamma$ によって生じる 成分であり、質量中心から距離 $r_{m}$ にある点の、質量中心に対する $x$ 方向相対変位である。 $\Delta u_{x}$ との違いを図 8 に示しておく。また、木 質構造の水平構面では式 22(b)の $\beta$ における $G V$ を定義し難いが、こ れと水平構面の面内せん断実験より得られるせん断剛性との関係を 付録 $\mathrm{A}$ に示した。

以上、式(8)の各マトリクス $\mathbf{m}, \mathbf{c}, \mathbf{k}$ は、非剛床の場合、次式のよ うに書き換えられる。

$$
\begin{aligned}
& \mathbf{m}=\left[\begin{array}{lll}
1 & 0 & 0 \\
0 & 1 & \alpha \\
0 & \alpha & 1
\end{array}\right], \quad \mathbf{u}=\left\{\begin{array}{c}
u_{x} \\
\left.\Delta u_{x}\right\} \\
\Delta u_{x}^{\prime}
\end{array}\right\}, \quad\{\mathbf{1}\}=\left\{\begin{array}{l}
1 \\
0 \\
0
\end{array}\right\} \\
& \mathbf{c}=2 h_{x} \omega_{x}\left[\begin{array}{ccc}
1 & -\bar{e}_{y}^{\prime} & -\bar{e}_{y}^{\prime} \\
-\bar{e}_{y}^{\prime} & \frac{h_{\theta}}{h_{x}} \frac{\omega_{\theta}}{\omega_{x}} & \frac{h_{\theta}}{h_{x}} \frac{\omega_{\theta}}{\omega_{x}} \cos 2 \psi_{x}^{\prime} \\
-\bar{e}_{y}^{\prime} & \frac{h_{\theta}}{h_{x}} \frac{\omega_{\theta}}{\omega_{x}} \cos 2 \psi^{\prime} & \frac{h_{\theta}}{h_{x}} \frac{\omega_{\theta}}{\omega_{x}}
\end{array}\right] \\
& \mathbf{k}=\omega_{x}^{2}\left[\begin{array}{ccc}
1 & -\bar{e}_{y} & -\bar{e}_{y} \\
-\bar{e}_{y} & \frac{\omega_{\theta}^{2}}{\omega_{x}^{2}} & \frac{\omega_{\theta}^{2}}{\omega_{x}^{2}} \cos 2 \psi_{x} \\
-\bar{e}_{y} & \frac{\omega_{\theta}^{2}}{\omega_{x}^{2}} \cos 2 \psi_{x} & \frac{\omega_{\theta}^{2}}{\omega_{x}^{2}}\left(1+\frac{\beta^{2}}{\omega_{\theta}^{2}}\right)
\end{array}\right]
\end{aligned}
$$

$(24 a-e)$

非剛床時の㨭れの支配特性值は、剛床時に対して $\alpha, \cos 2 \psi_{x}$, $\cos 2 \psi_{x}^{\prime}, \beta / \omega_{\theta}$ の 4 種が追加されることが式(27)より分かる。 $\alpha$, $\cos 2 \psi_{x}, \cos 2 \psi_{x}^{\prime}$ はそれぞれ質量・剛性・粘性の分布が水平構面のせ
ん断変形に及ぼす影響を表し、 $\beta / \omega_{\theta}$ が水平構面のせん断剛性の相 対的な大きさを表す(4.1 節)。
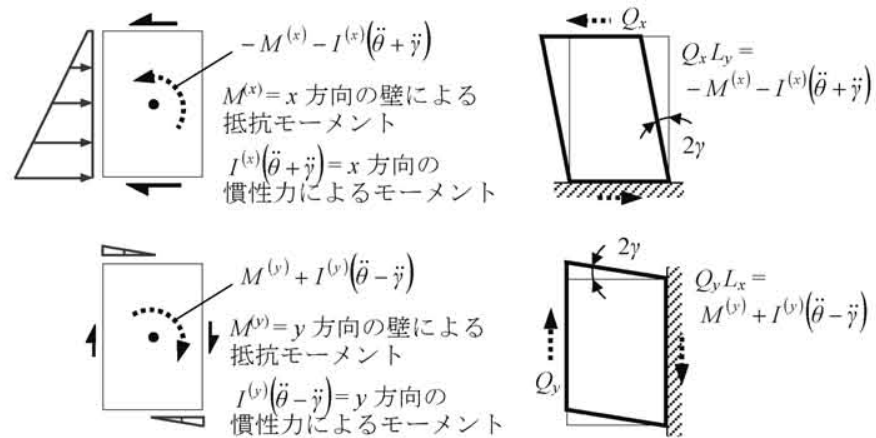

(a) 水平構面を介して釣り合う $x$ 方向・ $y$ 方向の力によるモーメント

(b) 等価なせん断力

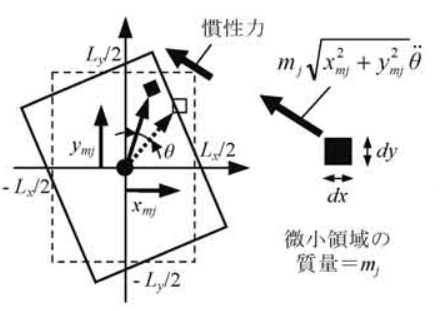

(a) 回転 $\theta$ が生じたとき
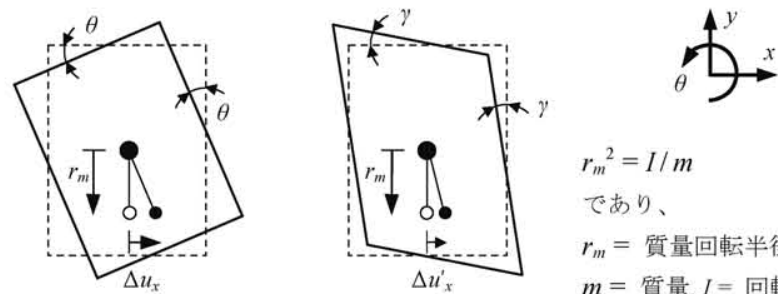

$r_{m}^{2}=I / m$

であり、

$r_{m}=$ 質量回転半径 $m=$ 質量, $I=$ 回転慣性

図 $8 \Delta u_{x}$ と $\Delta u_{x}^{\prime}$ の定義

\section{4. システムの動的特性}

\section{1 㨭れの支配特性值の想定範囲}

本節では、建物の剛性・粘性バランス、および水平構面の形状と 剛性を設定し、これらと据れの支配特性值の関係を検討する。

まず、図 9 のような構造モデルを考虑する。剛性要素・粘性要素 が外周部のみに接続され、剛性の大きさを長方形の長さで表した(粘 性要素は省略)。 $x$ 方向の剛性総和を $K$ とし、二つの構面に $a:(1-a)$ (た だし、 $0 \leq a \leq 0.5$ ) で分配する。 $y$ 方向の剛性総和を $b K$ とし、 $1: 1$ で 分配する。また、 $x$ 方向と $y$ 方向の辺長をそれぞれ $L, c L$ とする。

3 種のパラメータ $(a, b, c)$ に対する据れの支配特性值の変化を表 1 にまとめた。 $a$ は 0.5 から 0 まで変化するものとし、さらに参考の ため現行の耐震設計規準で定められた偏心率 $R_{e x}$ も併せて示した。 以下では比例減衰を仮定し、 $\bar{e}_{y}^{\prime}=\bar{e}_{y}, h_{\theta} / h_{x}=\omega_{\theta} / \omega_{x}, \cos 2 \psi_{x}^{\prime}=\cos 2 \psi_{x}$ と 寸る。 $b$ が増加すると、 $\omega_{\theta} / \omega_{x}$ の増加、 $\cos 2 \psi_{x}$ が減少する。c が増加 すると、 $\cos 2 \psi_{x}, \alpha$ ともに増加するが、 $\omega_{\theta} / \omega_{x}$ の変化は $b$ との関係 によって異なる。また、 $c$ が大きい場合、 $a=0$ に対応する $\bar{e}_{y}$ が増加 し、偏心率 $R_{e x}$ も非常に大きくなる。 
次に、 $\left(\beta / \omega_{\theta}\right)^{2}$ を式(4b), (22b)を用いて書き直すと、

$$
\left(\beta / \omega_{\theta}\right)^{2}=4 G V / K_{\theta}
$$

となる。すなわち、 $\left(\beta / \omega_{\theta}\right)^{2}$ とは水平構面にモーメントを与えたと きの床版の面内せん断剛性 $G V($ 式(13)) と、水平構面を剛床とした場 合に各壁が寄与する据れ剛性 $K_{\theta}($ 式(1b))の比を表している。

上述した床版の面内せん断剛性 $G V$ は、床倍率 $\alpha_{f}$ に比例すると考 えて差し支えないだろう。例えば、床倍率が 1/150rad.時の耐力で決 まるものとし、そのときの割線剛性でせん断剛性を定義すれば、 $G V$ は近似的に次のように書き換えられる ${ }^{8)}$ 。

$$
G V=1.96 \times 150 \alpha_{f} L_{x} L_{y}
$$

同様に、各壁の剛性が壁倍率に比例すると考え、 $K_{\theta}$ を $x$ 方向の壁 量 $\alpha_{x}\left(\mathrm{~m} / \mathrm{m}^{2}\right)$ と、前述のパラメータ $(b, c)$ を用いて書き換えれば、

$$
K_{\theta}=\frac{1.96 \times 150 \alpha_{x} L_{x} L_{y}\left(b+c^{2}\right)}{h}\left(\frac{L_{x}}{2}\right)^{2}
$$

ここに、 $h=$ 階高 $(\mathrm{m})$ であり、式(29)と同様に壁倍率が 1/150rad.時の 耐力で決まるものとして求めた。式(26), (27)を式(25)に代入すれば、

$$
\left(\beta / \omega_{\theta}\right)^{2}=\frac{16 \alpha_{f} h}{\alpha_{x} L_{y}^{2}\left(1+b / c^{2}\right)}
$$

式(28)から次のことが分かる。水平構面のせん断剛性の相対的な 大きさを表す $\left(\beta / \omega_{\theta}\right)^{2}$ は、床倍率 $\alpha_{f}$ に比例し、壁量 $\alpha_{x}$ に反比例する。 このことは、壁量が多い建物はそれに応じた高い床倍率の水平構面 が必要となることを表している。また、 $b$ が高く $c$ が低いほど、据 れに対して直交壁が抵抗しやすいことから、 $b / c^{2}$ とは㨭れ剛性に対 する直交壁の寄与の高さを表し、この值が高いほど $\left(\beta / \omega_{\theta}\right)^{2}$ は低下 する。さらに建物の立体的な形状を表す $h / L_{y}^{2}$ にも影響を受ける。

このように、 $\beta / \omega_{\theta}$ は床倍率のみの関数ではなく、他の様々なパ ラメータの影響を受ける。 $L_{x}=L_{y}=5.46 \mathrm{~m}(c=1)$, 壁量 $\alpha_{x}=0.15,0.3$, $0.45 \mathrm{~m} / \mathrm{m}^{2}$ の 3 種(付録 C), $b=0.5,1,2$ の 3 種とし、 $\beta / \omega_{\theta}=0.5,1,1.5$, 2,3 の 5 種に対応する床倍率 $\alpha_{f}$ を表 2 に例示した。上述の 5 種 $\beta / \omega_{\theta}$ 值に、 $\beta / \omega_{\theta}=0$ と、 $\beta / \omega_{\theta}=\infty$ (剛床と呼ぶ)を追加した計 7種の $\beta / \omega_{\theta}$ 值について、検討を行っていく。

\section{2 システムの動的特性}

$i$ 次モード $(i=1,2,3)$ に関して、固有円振動数 $\omega_{i}$, および固有心゙ クトル $\phi_{\mathrm{i}}$ は、次の実固有方程式の解として得られる。

$$
\left(-\omega_{i}^{2} \mathbf{m}+\mathbf{k}\right) \phi_{\mathrm{i}}=\mathbf{0}
$$

式(29)の解を得るには 3 次方程式を解く必要があるため、 $\omega_{i}$ や $\phi_{i}$ に 関して陽に表すことは実用的ではない。したがって、何らかの求根 アルゴリズムや固有値解析プログラムなどを用いて得ることとする。

木造住宅のような短周期構造では、高次モードの影響が極めて小 さく ${ }^{3)}$, よって以下では式(29)から得られる1次モードの固有円振動 数 $\omega_{1}$, 固有ベクトル $\phi_{1}=\left\{\phi_{11}, \phi_{21}, \phi_{31}\right\}^{\mathrm{T}}$ について議論を進める。こ こで、 $\phi_{j 1}$ とは 1 次モードの固有ベクトルにおける $j$ 番目の自由度の 要素であり、 $j=1$ は並進成分、 $j=2$ は回転成分、 $j=3$ は床せん断変 形成分である(図 10)。

$c=1$ とし、 $b=0.5,1,2$ の 3 種、 $\beta / \omega_{\theta}=0,0.5,1,1.5,2,3, \infty$ 7 種 について、 $a=0 \sim 0.5$ の範囲内での $\omega_{1} / \omega_{x}$, および $\phi_{1}$ の各成分のバ

\begin{tabular}{|c|c|c|c|c|c|c|}
\hline $\bar{b}$ & $\bar{c}$ & 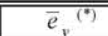 & $\overline{\omega_{\omega_{\theta}} / \omega_{x}}$ & 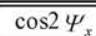 & $\bar{\alpha}$ & 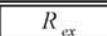 \\
\hline$\overline{0.5}$ & \multirow{3}{*}{0.5} & \multirow{3}{*}{$0 \sim 0.78$} & 1.34 & -0.33 & \multirow{3}{*}{-0.6} & $0 \sim 0.71$ \\
\hline 1 & & & 1.73 & -0.6 & & $0 \sim 0.5$ \\
\hline 2 & & & 2.32 & -0.78 & & $0 \sim 0.35$ \\
\hline 0.5 & \multirow{3}{*}{1} & \multirow{3}{*}{$0 \sim 1.23$} & 1.5 & 0.33 & \multirow{3}{*}{0} & $0 \sim 1.41$ \\
\hline 1 & & & 1.73 & 0 & & $0 \sim 1$ \\
\hline 2 & & & 2.12 & -0.33 & & $0 \sim 0.71$ \\
\hline 0.5 & \multirow{3}{*}{2} & \multirow{3}{*}{$0 \sim 1.55$} & 1.64 & 0.78 & \multirow{3}{*}{0.6} & $0 \sim 2.82$ \\
\hline 1 & & & 1.73 & 0.6 & & $0 \sim 2$ \\
\hline 2 & & & 1.9 & 0.33 & & $0 \sim 1.41$ \\
\hline
\end{tabular}
ランスを図 11 に示す。本論では特に $\left(\phi_{21}+\phi_{31}\right) / \phi_{11}$ のことを、「 $x$ 方

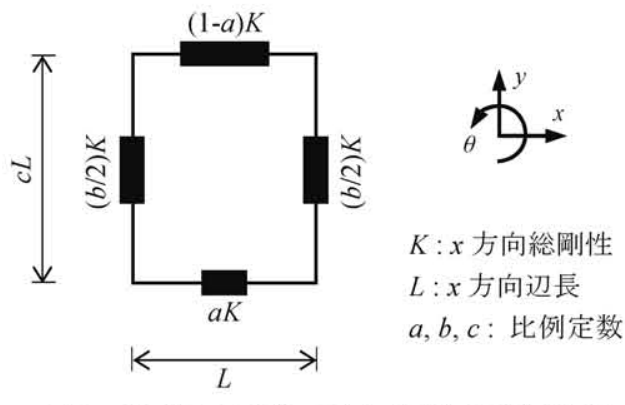

図 9 考慮する構造モデル (粘性要素を除く)

表 1 剛性バランス・床形状と㧖れの支配特性值の関係

$\left({ }^{*}\right) \quad a$ を 0.5 から 0 に変化させた場合

(**) 剛性比例型減衰のため、 $\bar{e}_{y}^{\prime}=\bar{e}_{y}, h_{\theta} / h_{x}=\omega_{\theta} / \omega_{x}, \cos 2 \Psi_{x}^{\prime}=\cos 2 \Psi_{x}$

表 $2 \beta / \omega_{\theta}$ の床倍率換算值

\begin{tabular}{c|c|c|c|c|c|c}
\hline \hline $\begin{array}{c}\text { 壁量 } \\
\left(\mathrm{m} / \mathrm{m}^{2}\right)\end{array}$ & $b$ & \multicolumn{5}{|c}{$\beta \omega_{\theta}$} \\
\hline \multirow{3}{*}{0.15} & 0.5 & 0.04 & 0.15 & 0.35 & 0.61 & 1.38 \\
\cline { 2 - 7 } & 1 & 0.05 & 0.20 & 0.46 & 0.82 & 1.84 \\
\cline { 2 - 7 } & 2 & 0.08 & 0.31 & 0.69 & 1.23 & 2.76 \\
\hline \multirow{3}{*}{0.3} & 0.5 & 0.08 & 0.31 & 0.69 & 1.23 & 2.76 \\
\cline { 2 - 7 } & 1 & 0.10 & 0.41 & 0.92 & 1.64 & 3.69 \\
\cline { 2 - 7 } & 2 & 0.15 & 0.61 & 1.38 & 2.46 & 5.53 \\
\hline \multirow{3}{*}{0.45} & 0.5 & 0.12 & 0.46 & 1.04 & 1.84 & 4.15 \\
\cline { 2 - 7 } & 1 & 0.15 & 0.61 & 1.38 & 2.46 & 5.53 \\
\cline { 2 - 7 } & 2 & 0.23 & 0.92 & 2.07 & 3.69 & 8.29 \\
\hline \hline
\end{tabular}

向の壁の変形モード」と呼ぶ。

$a=0.5$ (無偏心)のときは、 $\beta / \omega_{\theta}$ に関わらず $\omega_{1} / \omega_{x}=1$ となるが、 $a$ が低下寸るにつれて $\omega_{1} / \omega_{x}$ は低下し、その低下は $\beta / \omega_{\theta}$ が低いほど 著しい。また、 $b$ が高いほど $\beta / \omega_{\theta}$ の影響を大きく受ける。 $a=0$ か つ $\beta / \omega_{\theta}=0$ のモデルでは、 $b$ に関わらず $\omega_{1} / \omega_{x}=0$ に近付く。

$b=0.5$ と低い場合、等しい $a$ で比較すると $\beta / \omega_{\theta}$ の低下につれ $\phi_{21} / \phi_{11}$ は低下し、回転成分の寄与が小さくなっている。しかし、こ れに床せん断変形成分の寄与を加えた $\left(\phi_{21}+\phi_{31}\right) / \phi_{11}$ で見ると、 $b$ に関 わらず $\beta / \omega_{\theta}$ が低下するにつれ $\left(\phi_{21}+\phi_{31}\right) / \phi_{11}$ が増加し、 $x$ 方向の壁の 変形モードとしては据れが増加したような現象が起きる。( $\phi_{21}$ $\left.+\phi_{31}\right) / \phi_{11}$ に関しては、 $b$ が高いほど $\beta / \omega_{\theta}$ の影響を大きく受ける。

$\phi_{31} / \phi_{11}$ のグラフは、 $b$ が変化しても概形がほとんど変化しない。 このことは、床せん断変形成分の寄与は、ほぼ $a$ と $\beta / \omega_{\theta}$ で決定づ けられることを表している。文献 10 では、回転成分に対する床せん 断変形成分の比(本論の定義で言う $\left.\phi_{31} / \phi_{21}\right)$ が、剛性偏心の大小 $(=a$ の大小)によらないという結論を導いているが、特に $b$ が低いときに はそのような傾向が見られない。これは、文献 10 では静的な外力を 考慮していたためだと考えられる。 
また、既往文献 ${ }^{4)} て ゙$ 述べられているような、剛床に近い構造 $\left(\beta / \omega_{\theta}=\right.$ 大) ほど、直交壁への剛性付加による㨭れ抑制効果が有効 であることは図 11 の $\omega_{1} / \omega_{x} や\left(\phi_{21}+\phi_{31}\right) / \phi_{11}$ のグラフより明らかであ り、これまでに多数の時刻歷解析から得られた結論も、本論の評価 法によって、より定量的に示すことが可能となる。なお、 $\beta / \omega_{\theta}=0$ のとき、各動的特性値は $b$ の影響を受けない。これは直交壁が全く 機能しないことを表しており、付録 D に証明を示した。

ここで、剛床仮定が成立するクライテリアについて考えてみる。 例えば、後述する地震応答の傾向 (5.2 節) も含めて、 $\beta / \omega_{\theta}>1.5$ で あれば $\beta / \omega_{\theta}=\infty$ のケースと動的特性值や地震応答に大差はないよ うに思われる。表 2 から $\beta / \omega_{\theta}>1.5$ を満たす床倍率の下限值を読み 取ると、壁量 $=0.3 \mathrm{~m} / \mathrm{m}^{2}, b=1$ では床倍率 $>0.92$ であり、壁量 $=0.45$ $\mathrm{m} / \mathrm{m}^{2}, b=1$ では床倍率 $>1.38$ となる(ただし、 $L_{x}=L_{y}=5.46 \mathrm{~m}$ の場合) 許容応力度計算法 ${ }^{8}$ や精密診断法 $1^{13}$ では平均床倍率 $\geq 1$ が剛床のク ライテリアとされ、これらと比較して同等程度の要求值となり、現 代の木造軸組工法においても十分可能な要求と言える。ただし、前 述のごとく $\beta / \omega_{\theta}$ は床倍率のみの関数ではなく、直交壁の剛性や建 物の形状によって変化することに注意が必要である。

\section{3 水平構面の剛性を考慮した等価偏心率}

本節では、水平構面の剛性を考慮した等価な剛床モデルを構築し、
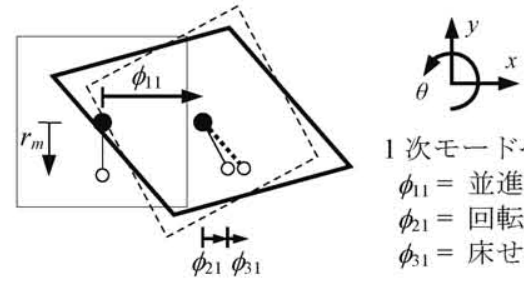

1 次モードベクトル $\phi_{1}^{\mathrm{T}}=\left\{\phi_{11}, \phi_{21}, \phi_{31}\right\}^{\mathrm{T}}$ $\phi_{11}=$ 並進成分

$\phi_{21}=$ 回転成分

$\phi_{31}=$ 床せん断変形成分

図 101 次モード形の定義
既往の評価法 ${ }^{10,11)}$ とは異なるアプローチによって等価偏心率を導出 することを試みる。

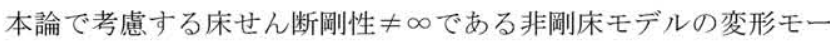
ドを図 12(左)に示す。これに対し、図12(右)のような床せん断剛性 = のである等価剛床モデルを新たに考慮する。これは明らかに非剛床 モデルと変形モードが異なるが、両モデルで $x$ 方向の壁の変形が等 しいという条件を設ける。また、図 12 より明らかなように等価剛床 モデルの方が $y$ 方向の壁の変形が大きくなる。

よって、非剛床構造の欠点を端的に言うと、直交壁の変形が減少 することにより、据れに対する直交壁の抵抗力が有効に作用しなく なることに他ならない。そこで、等価剛床モデルでは直交壁の変形 の減少を、剛性を $k$ 倍 $(0 \leq k \leq 1)$ に低減することに置き換え、非剛 床構造における $x$ 方向壁の変形モードを再現する。ここに、 $k=$ 有 効直交壁剛性比と呼び、以下のように得る。

直交壁の剛性低下は、剛床時に定義される据れの支配特性值のう ち $\omega_{\theta} / \omega_{x}$ にのみ影響を及ぼす。そこで、等価剛床モデルの $\omega_{\theta} / \omega_{x}$ を $\bar{\omega}_{\theta} / \omega_{x}$ と表す。また、等価剛床モデルの 1 次固有円振動数 $\bar{\omega}_{1}$ は、式 (7), (8)に基づく実固有方程式を解くことで、次のように表される。

$$
\bar{\omega}_{1}^{2}=\frac{\omega_{x}^{2}}{2}\left[1+\frac{\bar{\omega}_{\theta}^{2}}{\omega_{x}^{2}}-\sqrt{\left(1+\frac{\bar{\omega}_{\theta}^{2}}{\omega_{x}^{2}}\right)^{2}-4\left(\frac{\bar{\omega}_{\theta}^{2}}{\omega_{x}^{2}}-\bar{e}_{y}^{2}\right)}\right]
$$

式(30)を $\bar{\omega}_{\theta} / \omega_{x}$ について解けば、

$$
\frac{\bar{\omega}_{\theta}}{\omega_{x}}=\sqrt{\frac{\bar{\omega}_{1}^{2}}{\omega_{x}^{2}}+\frac{\bar{e}_{y}^{2}}{1-\bar{\omega}_{1}^{2} / \omega_{x}^{2}}}
$$
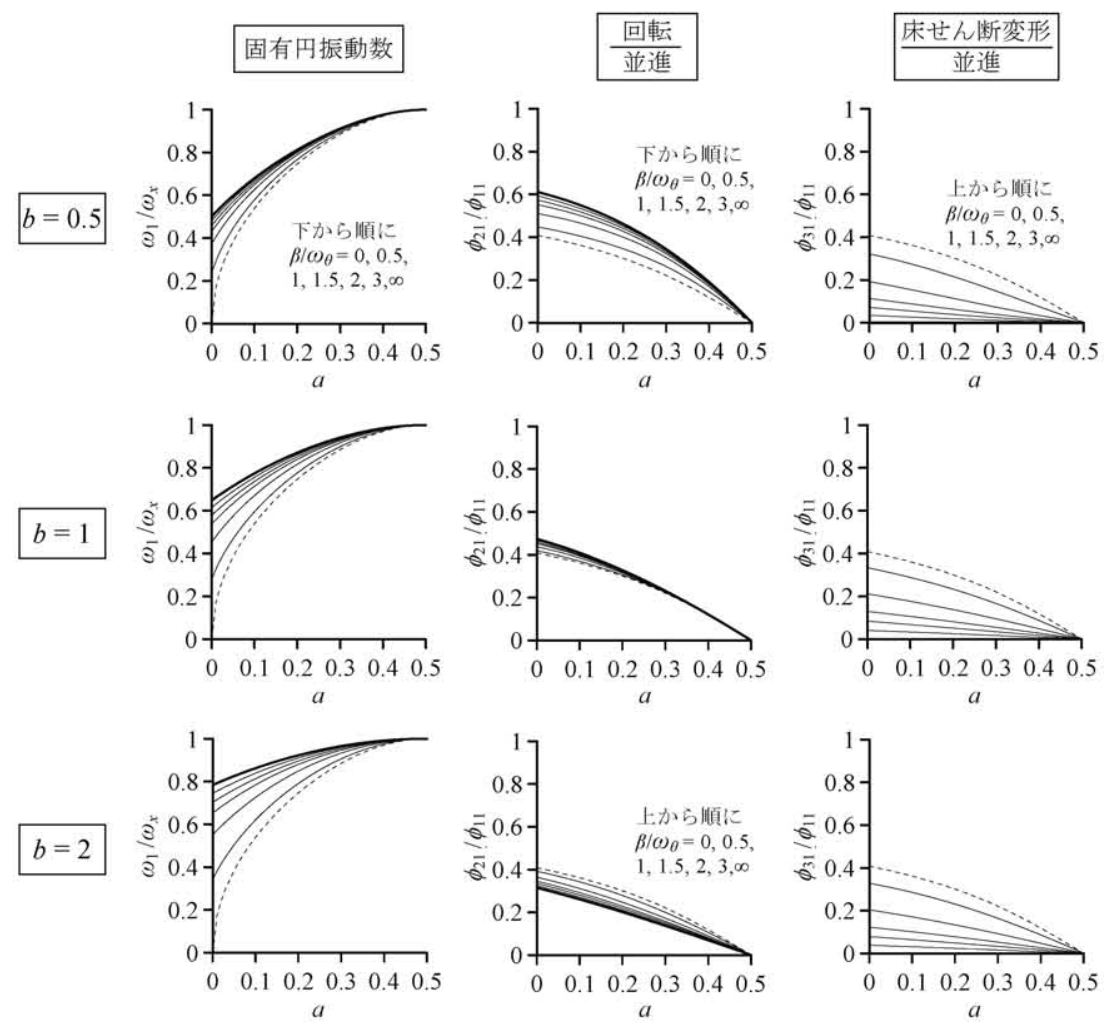
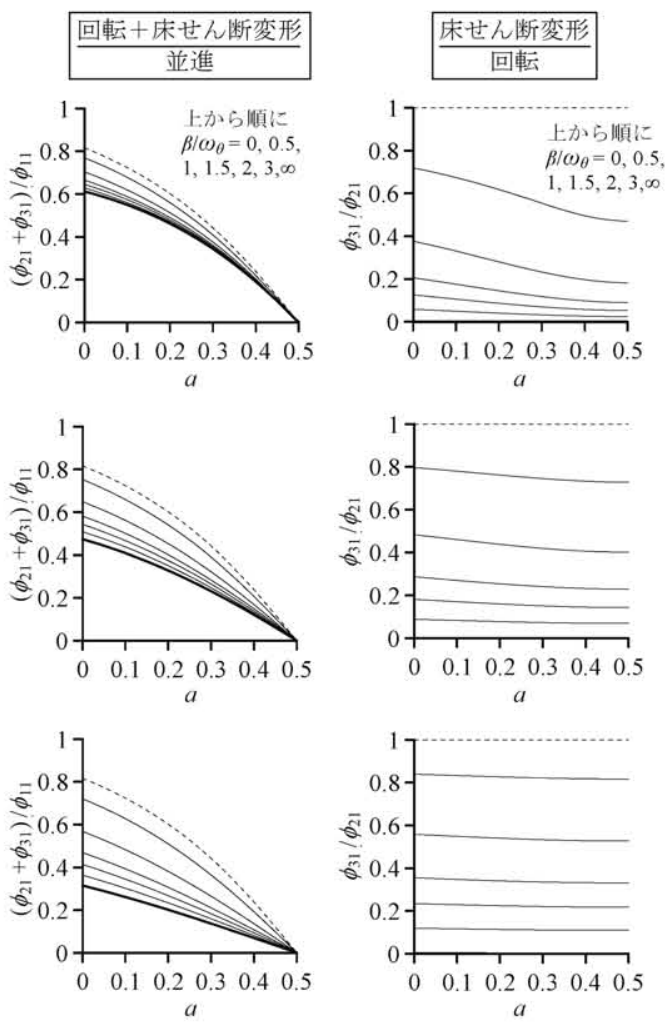

図 $11 \beta / \omega_{\theta}$ とシステムの動的特性の関係 $\left(\beta / \omega_{\theta}=0\right.$ (破線), $0.5,1,1.5,2,3, \infty$ (太線), $\left.c=1\right)$ 
モデルの $\omega_{1}$ を代入する。そして、式(31)を満たす $\bar{\omega}_{\theta} / \omega_{x}$ から $k$ を求 めれば、両モデルの 1 次固有円振動数は等しく、さらに $x$ 方向の壁 の変形モードも等しくなる(付録 $\mathrm{E})$ 。また、この $k$ を用いて計算され る偏心率を、「等価偏心率 $\left.\bar{R}_{e x}\right\lrcorner$ と呼ぶ。

まず、有効直交壁剛性比 $k$ の変化を図 13(左)に示す。他の変動要 因は図 11 と同様である。 $\beta / \omega_{\theta}=\infty$ の場合を除き、 $a$ が 0.5 から低下 するにつれ $k$ は低下し、 $\beta / \omega_{\theta}$ が低いほど $k$ も低い。また、同じ $a, \beta / \omega_{\theta}$ で比較すると、 $b$ が大きいほど $k$ は低くなる。 $\beta / \omega_{\theta}=0$ かつ $a=0$ の場合には $k=0$ となり、直交壁は全く機能しない(付録 D)。
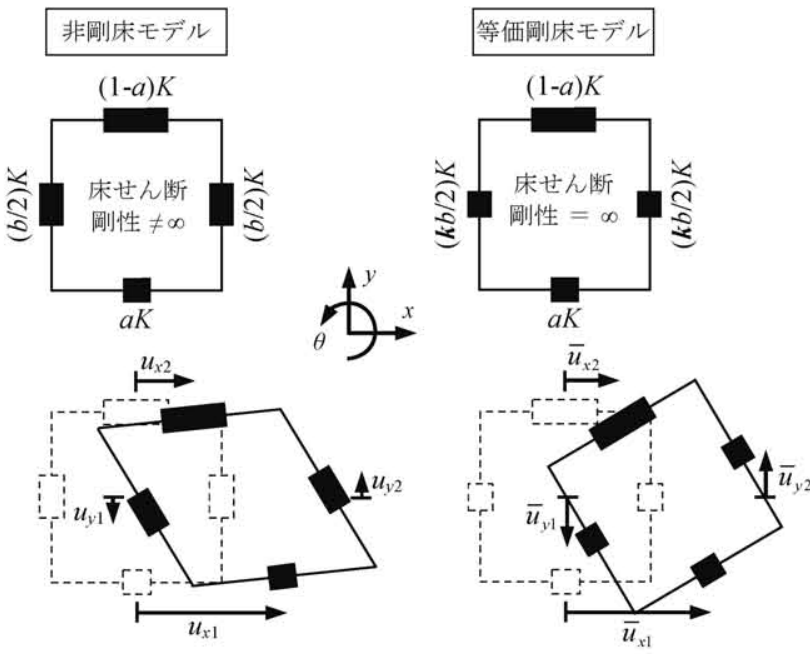

$u_{x 1}=\bar{u}_{x 1}, \quad u_{x 2}=\bar{u}_{x 2}$

$(x$ 方向の壁の変形は等しい $)$ $\left|u_{y 1}\right|=\left|u_{y 2}\right| \leqq\left|\bar{u}_{y 1}\right|=\left|\bar{u}_{y 2}\right| \quad(y$ 方向の壁の変形は等しくない

$\rightarrow$ 等価剛床モデルでは、直交壁の剛性に有効比 $\boldsymbol{k}$ を乗じる 図 12 非剛床モデルと等価剛床モデルの関倸
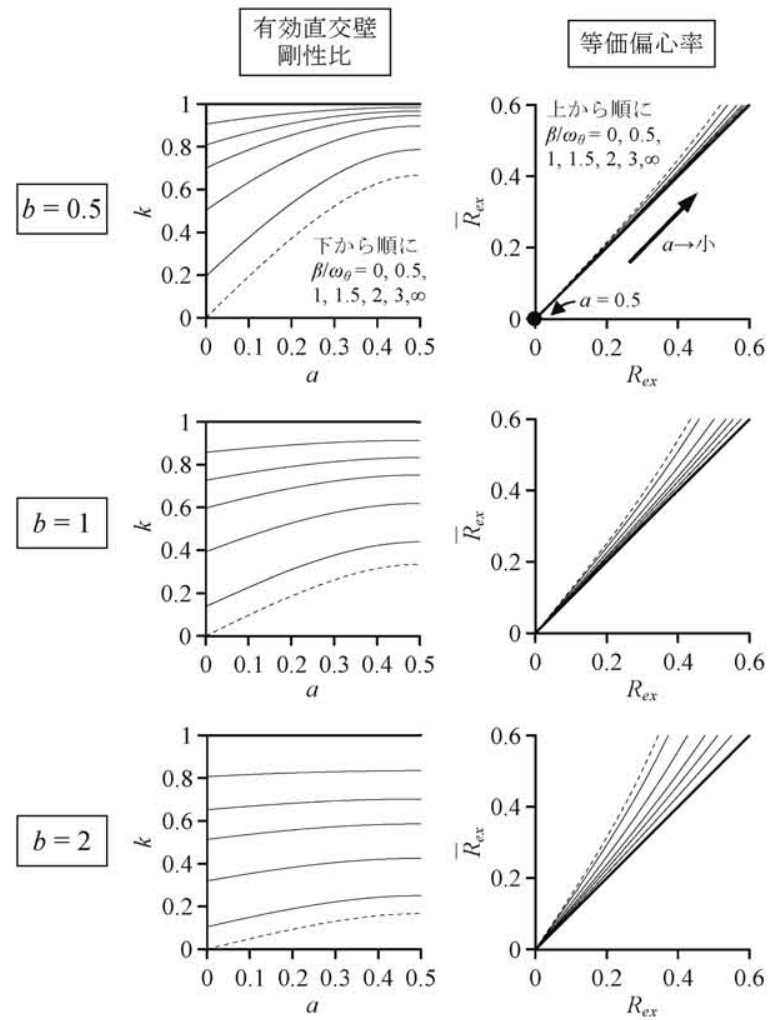

図 13 有効直交壁剛性比 $k$ と等価偏心率 $\bar{R}_{e x}$ $\left(\beta / \omega_{\theta}=0\right.$ (破線), $0.5,1,1.5,2,3, \infty$ (太線), $c=1$ )
図 13(右)は、剛床仮定に基づく偏心率 $R_{e x}$ と等価偏心率 $\bar{R}_{e x}$ の関係 を表している。 $b=0.5$ の場合、 $\beta / \omega_{\theta}$ に関わらず $\bar{R}_{e x} \approx R_{e x}$ となるが、 $b=1$ や 2 の場合、 $R_{e x}$ に比べて $\bar{R}_{e x}$ が明らかに増加する。 $R_{e x}=0.3$ のときの $\bar{R}_{e x}$ を、 $\beta / \omega_{\theta}=0,1,2$ の順に示すと、 $b=1$ では $\bar{R}_{e x}=0.38$, 0.34, 0.31 であり、 $b=2$ では $\bar{R}_{e x}=0.51,0.4,0.34$ となる。

このように、非剛床の場合には直交壁剛性が有効に機能しなくな ることに起因し、見掛け上、偏心率が増加したかのような現象が起 こる。この現象を、動的な運動方程式に基づき示すことができた。

\section{5. システムの地震応答の分析}

4 章ではシステムの動的特性評価を行い、さらに 4.3 節では等価 偏心率を定義し、剛床仮定に基づく偏心率計算との比較を行った。 しかし、偏心率のみではシステムの地震応答を評価できないことは 明らかであり、本論の目的も偏心率のような㨭れ応答の指標を提案 することではない。これまでの非剛床構造に関する研究では、建物 の固有円振動数・減衰定数・固有ベクトルのような動的特性值を用 いてシステムの地震応答を評価し、これと構造モデルの剛性バラン スや水平構面の剛性との関係を詳細に分析した例はなく、まずは非 剛床構造における地震応答の基本的な傾向を論じる必要がある。

5. 1 スペクトルー定領域における 1 次モード応答

本論では簡素化のため、入力地震動はその擬似加速度応答スペク トル $S_{p a}$ で定義し、システムの固有周期は加速度一定領域にあると する。また、前述のごとく 1 次モードによる応答のみ考慮する。

式(29)から得られる 1 次固有ベクトル $\phi_{1}$ を用い、1 次モード刺激係 数 $\beta_{1}$ を次式のように得る。

$$
\beta_{1}=\phi_{1}{ }^{\mathrm{T}} \mathbf{m}\{\mathbf{1}\} / \phi_{1}{ }^{\mathrm{T}} \mathbf{m} \phi_{1}
$$

また、 $C_{0}=0.2$ に相当する外力を想定し、 $5 \%$ 减衰における擬似加速 度応答值を $S_{p a}\left(h_{0}=0.05\right)=196 \mathrm{~cm} / \mathrm{s}^{2}$ とすれば、システムの最大応答 変位を与える変位ベクトル $\mathbf{u}_{\max }$ は、次式のように表される。

$$
\mathbf{u}_{\max }=\beta_{1} \phi_{1} S_{p a}\left(h_{0}=0.05\right) / \omega_{1}^{2}
$$

本論ではあまり減衰定数の高くない構造を対象とするため、前述の ような剛性比例型の減衰の仮定も不確かと言える。よって、以下の 検討では 1 次モードの減衰定数が常に $5 \%$ であるとし、減衰による 応答の低減を考慮しない。

\section{2 最大応答変位分布の傾向}

$a=0.15,0.2,0.25,0.33,0.4$ の 5 種、 $\beta / \omega_{\theta}=0,0.5,1,1.5,2,3, \infty$ の 7 種の組み合わせについて、式(33)より求まる最大応答変位分布を図 14 に示す。質量中心 ・柔側壁 $(x$ 方向の剛性が低い側 $)$ ・剛側壁 $(x$ 方向の剛性が高い側) の 3 点における最大応答変位を比較しており、 各ケースの剛床時の偏心率 $R_{e x}$ を図中に括弧書きで示した。なお、 $T_{x}\left(=2 \pi / \omega_{x}\right)=0.4$ 秒とした。

図 14(a)は $c=1$ で固定し、 $b=0.5,1,2$ の 3 種について比較した結 果である。図の右から左の順に $a$ が小さく(剛性偏心が大きく), 下か ら上の順に $b$ が小さく (直交壁剛性が小さく) なる。 $a$ が小さいシス テムほど、 $\beta / \omega_{\theta}$ の変化に対して最大応答変位が影響を受けやすく なる。すなわち、 $\beta / \omega_{\theta}$ が低下するほど柔側壁の最大変位が増加し、 見掛け上技れが大きくなる。さらに特筆すべきは、 $a$ が小さいシス テムほど、 $\beta / \omega_{\theta}$ の低下によって質量中心の最大変位も増加するこ とである。これは、水平構面剛性の低下により、剛側壁や直交壁が 
据れに対して抵抗しにくくなり、的が低下したことが要因である ${ }^{2)}$ 木造住宅のような短周期構造では、応答変位が周期の 2 乗に比例す るため、上述した水平構面剛性の低下は、質量中心の並進変位も増 加させやすいことに注意しなければならない。応力集中率や㨭れ補 正係数を用いた既往の評価法では、剛床・非剛床に関わらず剛性中 心の変位を 1 に基準化した指標を用いるため、このような固有円振 動数の低下による並進変位の増加を考慮できない $5,10,11)$ 。

図 14(b)は $b=1$ で固定し、 $c=0.5,2$ の 2 種について比較した結果 である。 $b=1$ かつ $c=1$ のケースは図 14(a)の中段に示している。 $c=$ 2 では元々直交壁が据れに抵抗しにくい床形状のため、 $\beta / \omega_{\theta}$ が低下 しても最大応答変位には変化が現れにくい。言い換えると、 $c=0.5$
のように据れ剛性に対して直交壁の剛性が大きく寄与する構造ほど、 $\beta / \omega_{\theta}$ の低下が最大応答変位に大きく影響を与える。

以上、擬似加速度応答スペクトル一定という木造住宅に典型的な 傾向を踏まえた上で非剛床構造の地震応答を分析した結果、既往の 評価法では考慮していなかった点とその影響が明確となった。図 14 の全体的な傾向から、軸組工法における現行の規準 $R_{e x}<0.3$ に加え、 前述した $\beta / \omega_{\theta}>1.5$ を満足すれば、剛床時の最大応答変位と大差は ない、つまり、概ね剛床仮定が成立すると言えるだろう。また、 $a<$ 0.25 のように剛性偏心が著しく大きい構造や、 $b=2$ や $c=0.5$ のよう に建物の㨭れ剛性に対して直交壁の剛性が大きく寄与寸る構造の地 震応答は、特に水平構面の剛性に影響を受けやすく、 $\beta / \omega_{\theta}>1.5$ を

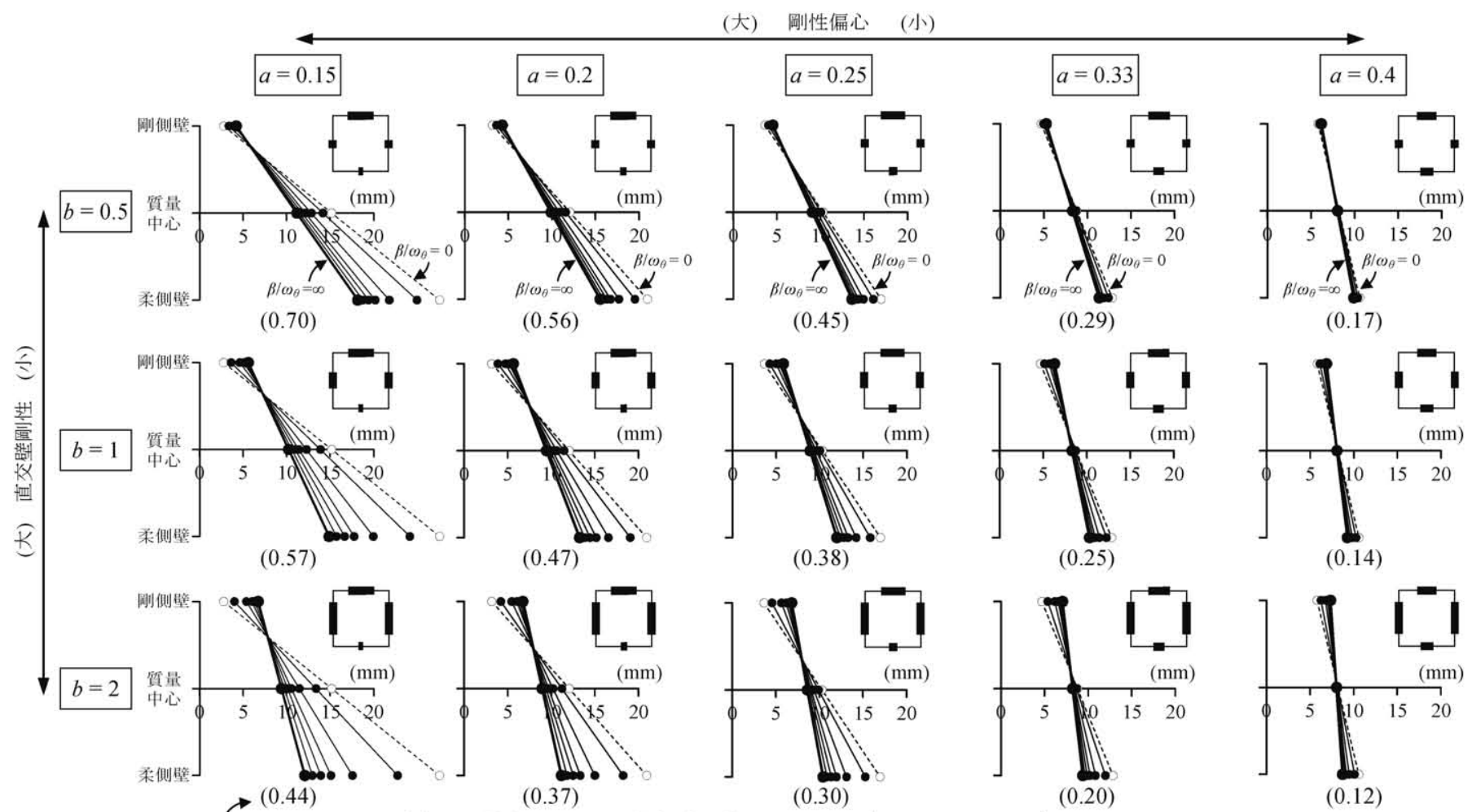

剛床時の偏心率 $R_{e x}$

(a) 剛性偏心 $(a)$ と直交壁剛性 $(b)$ による変化 $(c=1$ で固定)

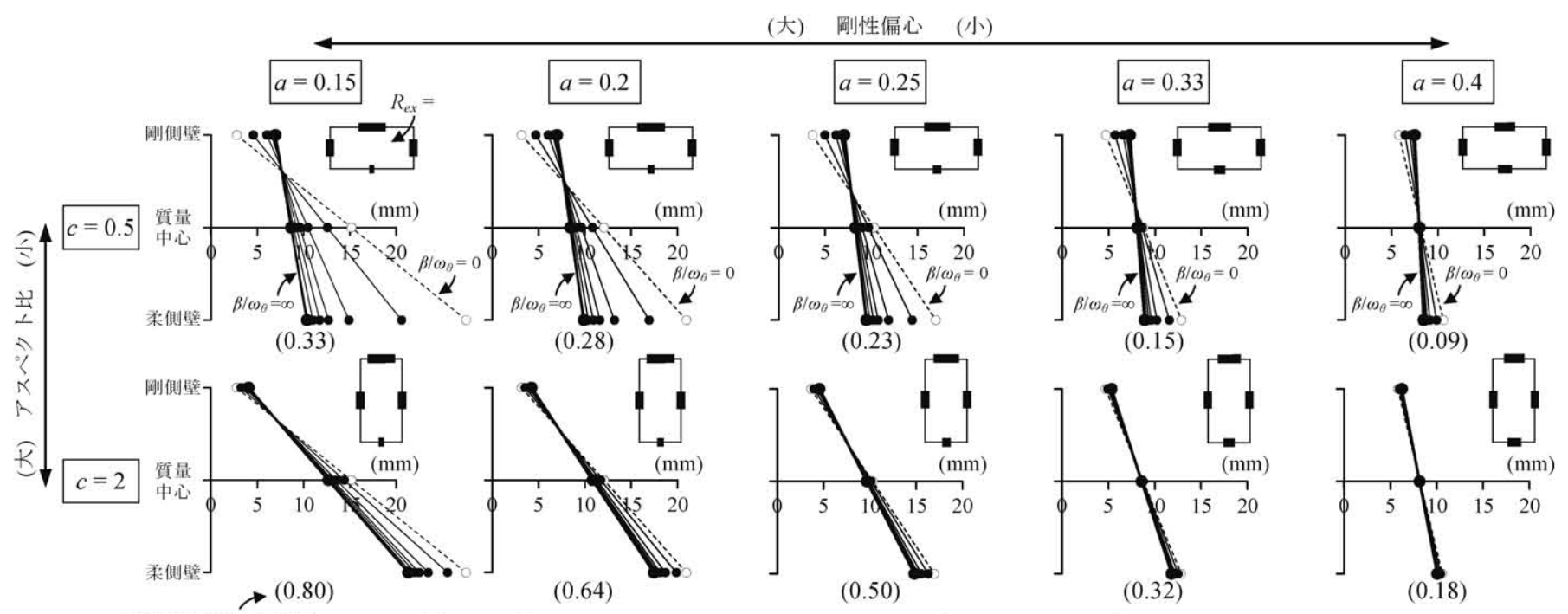

剛床時の偏心率 $R_{e x} \quad$ (b) 剛性偏心 $(a)$ とアスペクト比 $(c)$ による変化 $(b=1$ で固定)

図 14 加速度一定領域 $\left(S_{p a}=196 \mathrm{~cm} / \mathrm{s}^{2}\right)$ における最大応答変位 $\left(\beta / \omega_{\theta}=0\right.$ (破線), $0.5,1,1.5,2,3, \infty$ (太線)) 
満たさないケースの応答值は剛床時に比べて大きく異なる傾向を示 した。このことから、式(28)に $\beta / \omega_{\theta}=1.5, h=2.73 \mathrm{~m}$ を代入し、床 倍率 $\alpha_{f}$ に対して陽に表せば、次式を得る。

$$
\alpha_{f}=0.052\left(1+b / c^{2}\right) \alpha_{x} L_{y}^{2} \approx \frac{L_{y}\left(1+b / c^{2}\right)}{9.7} \frac{\alpha_{x}}{2} L_{y}
$$

式(34)は剛床仮定を満たす最小床倍率を表し、右辺の $L_{y}\left(1+b / c^{2}\right) / 9.7$ は、品確法の必要床倍率算定式における $\alpha$ に相当する ”。ここに、 品確法の $\alpha$ は境界条件を表す係数であり、0.5 2 となる(式(22a)の $\alpha$ とは異なる)。式(34)は非剛床構造における㨭れ振動時の動的特性を 剛床時のそれに近付けるという観点から誘導した必要值であり、直 交壁の剛性 $(b)$ や辺長比 $(c)$ が含まれる。ただし、 $\beta / \omega_{\theta}>1.5$ とい うクライテリアに関しては、さらに精査する必要があると思われる。

\section{6. おわりに}

本論では、非剛床構造の動的特性評価法を提案し、これに基づき 地震応答の傾向を分析した。以下にまとめる。

1) 水平構面のせん断剛性の高さは $\left(\beta / \omega_{\theta}\right)^{2}$ (式(24e)の 3 行 3 列)によ って表され、このパラメータには二つの解釈ができる。一つは、 水平構面の面内せん断剛性 $G V$ と、剛床の場合に各壁が寄与する 㨭れ剛性 $K_{\theta}$ の比 (式(25)) であること。二つ目は、床倍率や壁量、 建物の形状によって決まる值 (式(28)) という解釈である。

2) 水平構面剛性とシステムの動的特性の関係は、式(29)の固有值問 題を解くことで得られ、図 11 のように図示される。

3) 水平構面のせん断変形によって直交壁の変形が減少することを、 直交壁の剛性低下に置き換えることで、水平構面の剛性を考慮し た等価偏心率の算出を行った(図 13)。

4) 水平構面剛性 $\left(\beta / \omega_{\theta}\right)$ の低下は、見掛けの㧖れを増加させるだけ でなく、 1 次固有円振動数の低下により、質量中心の並進変位も 増加させる(図 14)。

5) 1)で述べた $\beta / \omega_{\theta}$ 值が 1.5 以上であれば、建物の動的特性や地震応 答の面でも概ね剛床仮定が成立する。これを床倍率に対して陽に 表すと式(34)になり、剛床仮定を満たす必要床倍率を表している。

6) 剛性偏心が大きい構造や、据れ剛性に対して直交壁の剛性が大き く寄与する構造では、水平構面剛性 $\left(\beta / \omega_{\theta}\right)$ )低下が最大応答変 位に大きく影響を与える(図 14(b))。このような構造で $\beta / \omega_{\theta}>1.5$ を満たさない場合、剛床仮定に基づく解析では応答值に多大な誤 差が生じるため、水平構面の剛性を考慮する必要がある。

なお、本論は $1 \times 1$ スパンを対象としており、多スパンの建物に対 してそのまま適用することはできないが、例えばゾーニングにより $2 \times 1$ スパンに近似することが可能であれば、 4 自由度系に拡張して 同様の展開が可能と考えられる。さらに多スパンの場合でも、図 3(a) のように床をせん断パネルの集合と考えれば、隣接する耐力壁線間 $(1 \times 1$ スパン) の領域では平行四辺形の変形モードとなり、本論で得 た有効直交壁剛性比 $k$ に関する知見を適用できる可能性がある。

また、本論では質量が平面内に均等に分布している場合を扱った が、これと異なる質量分布の場合であっても式(11)の值が変化する のみであり、㧖れの支配特性値が表 1 に示した值と同等であれば、 本論と等しい結果が得られる。したがって、本論の結果は表 1 の据 れの支配特性值に基づく結論であると換言できる。
最後に、筆者らは耐力壁 (鉛直構面) が非線形領域にあっても、 一軸偏心建物の地震最大応答を等価線形化手法によって予測可能で あることを文献 3 で示した。同様に、本論で示した非剛床構造の運 動方程式から、水平構面の非線形化も含めた等価線形化が可能であ ると考えており、さらに将来的には簡便化を図るため、静的解析に よるアプローチへの展開も必要となるだろう。前述の課題も含めて 今後検証を行っていきたい。

\section{参考文献}

1) 日本建築学会ほか：阪神・淡路大震災調査報告 建築編- 4 , 阪神・淡路 大震災調査報告編集委員会, pp.228-231, 1998.3

2) 阿川将樹, 腰原幹雄, 佐藤孝浩, 大橋好光, 宮澤健二：偏心を有する木質 面材耐力壁構造の動的性状に関寸る実験的研究, 日本建築学会構造系論 文集, 第 558 号, pp.157-164, 2002.8

3) 山崎義弘, 笠井和彦, 坂田弘安, 大木洋司：剛性偏心した木質立体架構 の粘弾性ダンパーによる㧖れ応答制御, 日本建築学会構造系論文集, 第 655 号, pp.1961-1700, 2010.9

4) 山田明, 鈴木三四郎：床剛性を考慮した軸組木造長屋モデルの直交壁効 果に関する考察 2 方向の地震入力を受ける場合, 日本建築学会構造系論 文集 第 634 号, pp.2143-2150, 2008.12

5) 宮澤健二, 正田慎二, 西村彰敏：木質系住宅の水平構面剛性と立体動的 偏心に関する研究, 日本建築学会大会学術講演梗概集, C-1 分冊, pp. $277-278,2010.9$

6) 清水秀丸, 向坊恭介, 堀川恵巳子, 槌本敬大, 河合直人, 大橋好光 : 実大 震動台実験による伝統的な木造建物の耐震性能検証に関する研究 部材 断面が大きな地方型試験体の震動台実験結果, 日本建築学会構造系論文 集, 第 657 号, pp.2001-2008, 2010.11

7) 国土交通省住宅局住宅生産課ほか：日本住宅性能表示基準·評価方法基 淮技術解説(新築住宅)2010, 工学図書(株), pp.111-125, 2010.10

8) (財) 日本住宅・木材技術センター：木造軸組工法住宅の許容応力度設計 (2008 年版), pp.75-76, 2009.6

9) 村上雅英, 稲山正弘：偏心を有する柔床壁式構造物の勒性設計法, 日本 建築学会構造系論文集, 第 530 号, pp.93-98,2000.4

10) 梶川久光, 野口弘行：1 層箱形建物における剛床仮定の適用範囲に関寸 る研究：木質立体建物の床剛性を考慮した水平ねじれ挙動に関寸る研究, 日本建築学会構造系論文集 第 595 号, pp.79-85, 2005.9

11) 小谷竜城, 景山誠, 村上雅英, 稲山正弘：水平構面の剛性を考慮した偏 心率及びねじれ補正係数の提案及び検証 1 スパンモデルの場合，日本 建築学会構造系論文集, 第 654 号, pp.1483-1490, 2010.8

12) 野口弘行, 和木洋, 内山善明, 渡邊康志：水平構面剛性を考慮した 2 層木 質建物の振動性状に関する研究(その 4)：壁量・壁配置に関する簡易構 造検討法の提案, 日本建築学会大会学術講演梗概集 C-1 分冊, pp.225-226, 2008.7

13) 日本建築防災協会：木造住宅の耐震診断と補強方法, pp.74-75, 2006.6

14）志賀敏男：構造物の振動, 共立出版, pp. 140-184, 1976.6

15) C. L. Kan and A. K. Chopra : Effects of Torsional Coupling on Earthquake Forces in Buildings, Journal of the Structural Division, Proceedings of the ASCE, Vol. 103, No.4, pp. 805-819, 1977.4

16) 笠井和彦, 山下忠道, 山崎義弘, T. IGUSA：据れ振動をともなう 1 層高減 衰構造のスペクトル応答予測法, 日本建築学会構造系論文集, 第 636 号, pp. 225-234, 2009.2

17) 河合直人：耐力壁の釣合い良い配置のための簡便法, 日本建築学会大会 学術講演梗概集, C-1 分冊, pp.237-238, 2001.7

18) 山田耕司：床剛性と雜壁を考慮した木造軸組建物の最大変位応答分布, 日本建築学会構造計論文集, 第 586 号, pp.131-137, 2004.12

19) 三宅辰哉, 腰原幹雄, 槌本敬大, 五十田博, 箕輪親宏 : 震動台による既存 木造住宅の耐震性能検証実験 その 11 震動台実験に対応する倒壊解析, 日本建築学会大会学術講演梗概集, C-1 分冊, pp.387-388, 2006.7

20 ) 後藤正美, 山口理恵, 稲山正弘 : 在来軸組工法木造住宅の構造設計手法 の開発その 5 水平構面の変形成分, 日本建築学会大会学術講演梗概集, C-1 分冊, pp.187-188, 1998.7

\section{付録 $\mathrm{A}$ 水平構面のせん断剛性に関する定義}

木質構造の床構法は、面材のみを直貼りする場合や、火打ちを併用する場 合など様々あり、その変形性状も純粋なせん断変形に近いものから、床組の 曲げ変形を伴うものがある(図 $\mathrm{Al}(\mathrm{a}),(\mathrm{b}))$ 。本論ではそのような変形性状の違 いを問わず、便宜上、せん断弾性係数 $G\left(\mathrm{kN} / \mathrm{m}^{2}\right)$, 厚さ $t(\mathrm{~m})$ の床版に置換して 
扱った。しかし、実現象を表わすには図 $\mathrm{Al}(\mathrm{a})$ のように、頂部にせん断力 $Q_{x}$ を与えたときの頂部変位を $\delta_{x}$ として、 $x$ 方向の面内せん断剛性 $K_{R, x}(\mathrm{kN} / \mathrm{rad}$. $)$ を 用いた方が都合が良い。すなわち、

$$
Q_{x}=K_{R, x} \gamma_{x} \quad, \quad \gamma_{x}=\delta_{x} / L_{y}
$$

ここに、 $\gamma_{x}=x$ 方向のせん断変形角, $L_{y}=y$ 方向の床長さである。また、床に加 えたモーメントを、

$$
M_{x}=Q_{x} L_{y}
$$

のように表せば、式(13a)の関係から、

$$
\begin{aligned}
& M_{x}=K_{R, x} L_{y} \gamma_{x}=2 G V \gamma \\
& \therefore G V=K_{R, x} L_{y} \quad\left(\because \gamma_{x}=2 \gamma\right)
\end{aligned}
$$

すなわち、 $G V$ は水平構面の面内せん断㑉性 $K_{R, x}$ に、床の幅 $L_{y}$ を乗じた值と して扱えば良い。 $K_{R, x}$ は水平構面の面内せん断実験より得られる。

ここで、水平構面のせん断挙動に異方性がある場合を考えておく。すなわ ち、図 $\mathrm{Al}(\mathrm{b})$ のように、図 $\mathrm{Al}$ (a) とは直交方向にせん断力を与えたとき、その モーメント $M_{y}$ とせん断変形角 $\gamma_{y}$ が、次のような関係となる場合である。

$$
M_{y}=K_{R, y} L_{x} \gamma_{y}
$$

ここに、 $K_{R, y}=y$ 方向の面内せん断剛性である。本論のようにせん断弹性係数 $G$, 厚さ $t$ の床版では、 $M_{x}=M_{y}$ のときに $\gamma_{x}=\gamma_{y}$ となるため、式(A3), (A4)より、

$$
\begin{aligned}
K_{R, x} L_{y} \gamma_{x} & =K_{R, y} L_{x} \gamma_{y} \\
\therefore K_{R, y} L_{x} & =K_{R, x} L_{y} \quad\left(\because \gamma_{x}=\gamma_{y}\right)
\end{aligned}
$$

すなわち、本論で扱う水平構面は $x$ 方向と $y$ 方向それぞれの面内せん断剛性 が、加力方向の床長さ (奥行き) に比例する (式(A5)) 必要がある。図 $\mathrm{Al}(\mathrm{a})$ に示寸ように面材を釷打ちした水平構面の場合、上述の仮定は十分成立しう ると考えられる。

\section{付録 B 木質構造における水平構面のせん断変形と質量の変位}

本論で示寸評価法の特長の一つに、水平構面の回転およびせん断変形に伴 う慣性力分布の変動を考慮することが举げられる。ただしこの現象は、水平 構面内に分布した質量が、床のせん断変形に追従して変位することを前提と している。

木質構造の水平構面の例として、構造用合板あるいは杉板を釷打ちした床 や、最上層にあっては切妻屋根が挙げられる。これらの水平構面のせん断挙 動は、面材を接合する釘の変形、根太や垂木の転びなどが変形の主成分であ り、面材自体のせん断変形成分は少ない ${ }^{20)}$ 。しかし、図 B1 のように水平構 面内に多くの面材が並べられた状態を考えれば、個々の面材間に相対ずれが 生じ、面材の集合体として見ると、一枚の床面にせん断変形が生じたかのよ うな挙動として捉えられる。したがって、建物内の各部に存在する個々の質 量の変位は、水平構面が平行四辺形にせん断変形すると仮定して求めた場合 の質量の変位に等しいと考えられ、図 7 のようにして慣性力を算出したこと が妥当であると言える。

\section{付録 C 本論で考慮した壁量}

建築基淮法の壁量計算で定められた重い建物の必要壁量は、平屋で 0.15 $\mathrm{m} / \mathrm{m}^{2}, 2$ 階建ての 1 階で $0.33 \mathrm{~m} / \mathrm{m}^{2}$ であり、一方、品確法の壁量計算で定めら れた重い建物の必要壁量は、 2 階建ての 1 階で $0.46 \mathrm{~m} / \mathrm{m}^{2}$ である。本論 4.1 節 の検討(表 2)で考慮した 3 種の壁量 $\alpha_{x}=0.15,0.3,0.45 \mathrm{~m} / \mathrm{m}^{2}$ は、ここに述べた 值を基に設定した。

\section{付録 D $\beta / \omega_{\theta}=0$ のときの固有値}

$\beta / \omega_{\theta}=0$ のときの実固有方程式は、式(29)における $\operatorname{det}\left(-\omega^{2} \mathbf{m}+\mathbf{k}\right)=0$ から次 のように得られる。

$\left(1-\alpha^{2}\right) \Omega^{3}-\left[\left(1-\alpha^{2}\right)+2\left(\omega_{\theta}^{2} / \omega_{x}^{2}\right)\left(1-\alpha \cos 2 \psi_{x}\right)\right] \Omega^{2}$

$$
+\left[-2(1-\alpha) \bar{e}_{y}^{2}+2\left(\omega_{\theta}^{2} / \omega_{x}^{2}\right)\left(1-\alpha \cos 2 \psi_{x}\right)+\left(\omega_{\theta}^{4} / \omega_{x}^{4}\right)\left(1-\cos ^{2} 2 \psi_{x}\right)\right] 2
$$$$
+\bar{e}_{y}^{2}\left[2\left(\omega_{\theta}^{2} / \omega_{x}^{2}\right)\left(1-\cos 2 \psi_{x}\right)-\left(\omega_{\theta}^{4} / \omega_{x}^{4}\right)\left(1-\cos ^{2} 2 \psi_{x}\right)\right]=0
$$

$$
\Omega=\left(\omega / \omega_{x}\right)^{2}
$$

式(D1)の $\bar{e}_{y}, \omega / \omega_{x}, \cos 2 \psi_{x}, \alpha$ を、 $a, b, c$ を用いて書き直せば、

$$
\begin{aligned}
& \Omega^{3}-(4+3 b) \Omega^{2}+3\left[4 b-(1-2 a)^{2}+1\right] \Omega+9 b\left[(1-2 a)^{2}-1\right] \\
= & {\left[\Omega^{2}-4 \Omega+12 a(1-a)\right](\Omega-3 b)=0 }
\end{aligned}
$$

よって、 $\Omega=\left(\omega / \omega_{x}\right)^{2}$ が次のように得られる。

$$
\Omega=2[1 \mp \sqrt{1-3 a(1-a)}], 3 b
$$

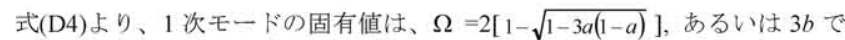
与えられる。 $0 \leq a \leq 0.5$ では $0 \leq 2[1-\sqrt{1-3 a(1-a)}] \leq 1$ のため、本論のように $b \geq 1 / 3$ では必ず $\Omega=2[1-\sqrt{1-3 a(1-a)}]$ が 1 次となり、 $\left(\omega_{1} / \omega_{x}\right)^{2}$ が $a$ のみに支配さ れる。同様に、他の固有值 $(2[1+\sqrt{1-3 a(1-a)}], 3 b)$ も、それぞれ $a$ と $b$ のみに支 配され、 $x$ 方向の壁と $y$ 方向の壁が同一のモードで働かないことを表している。
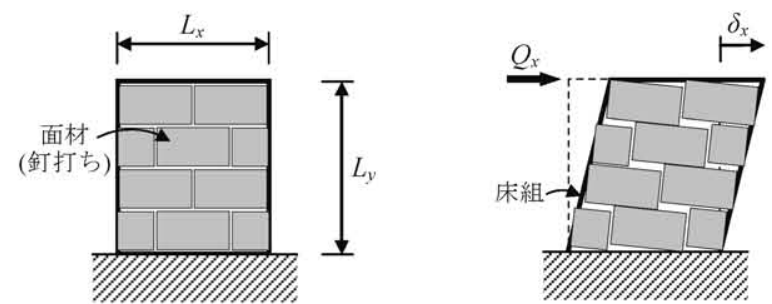

(a) 面材型 (せん断変形卓越)

$K_{f x}=Q_{x} / \gamma_{x} \quad(x$ 方向の面内せん断剛性 $)$

$M_{x}=Q_{x} L_{y}=K_{f x} L_{y} \gamma_{x} \quad\left(M_{x}=Q_{x} L_{y}\right)$

$\therefore G V=K_{f x} L_{y}$

$K_{f y}=Q_{y} / \gamma_{y} \quad(y$ 方向の面内せん断剛性)

とすれば、適合条件から、

$G V=K_{f x} L_{y}=K_{f y} L_{x}$

となる必要がある。

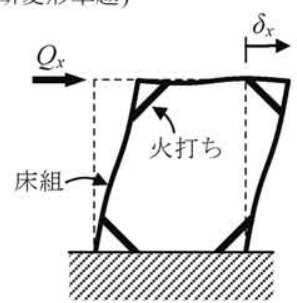

(b) 火打ち型 (曲げ変形卓越)

図 A1 水平構面のせん断挙動に関する仮定

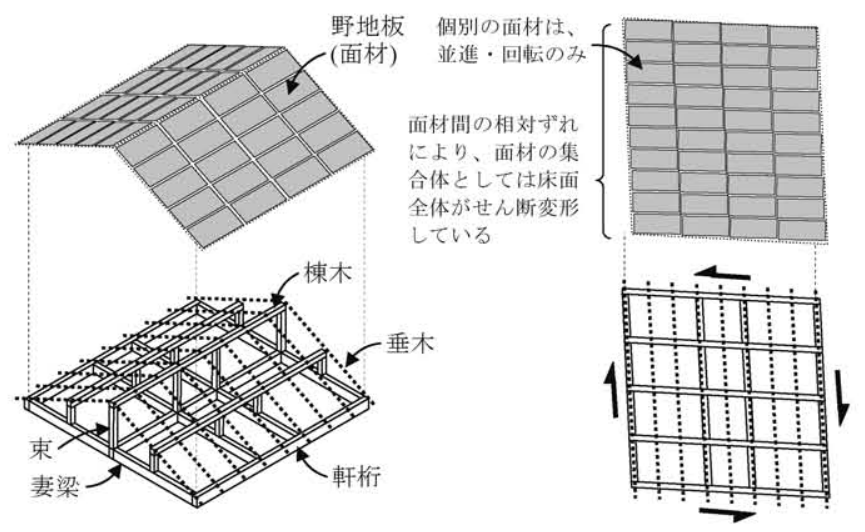

(a) アイソメトリック

(b) 平面図 (せん断変形時)

図 B1 水平構面のせん断挙動の例 (切妻屋根の場合)

\section{付録 $\mathrm{E}$ 非剛床モデルと等価剛床モデルの関係}

4.3 節では、非剛床モデルと等価剛床モデルの 1 次固有円振動数 $\omega_{1}$ が等し いという条件を設けた。このときの両モデルにおけるモード形や刺激係数の 関係を示しておく。

1 次モードの固有方程式は次式となる。

$$
\left(-\omega_{1}^{2} \mathbf{m}+\mathbf{k}\right) \phi_{1}=\mathbf{0}
$$

式(E1)の第 1 行に関する展開式から、1 次固有ベクトルの並進成分に対する回 転成分十床せん断変形成分の比と刺激係数 $\beta_{1}$ が、以下のように求まる。

$$
\frac{\phi_{21}+\phi_{31}}{\phi_{11}}=\frac{1-\omega_{1}^{2} / \omega_{x}^{2}}{\bar{e}_{y}} \quad, \quad \beta_{1}=\frac{\phi_{11}}{\phi_{11}^{2}+\phi_{21}^{2}+\phi_{31}^{2}+2 \alpha \phi_{21} \phi_{31}}
$$

$(\mathrm{E} 2 \mathrm{a}, \mathrm{b})$

また、等価剛床モデルの固有方程式は、式(E1)の $\mathbf{m}, \mathbf{k}$ に式(8a), (8e)t代入 することで得られ、固有ベクトルを $\bar{\phi}_{1}=\left\{\bar{\phi}_{11}, \bar{\phi}_{21}\right\}^{\mathrm{T}}$, 刺激係数を $\bar{\beta}_{1}$ とすれば、

$$
\frac{\bar{\phi}_{21}}{\bar{\phi}_{11}}=\frac{1-\omega_{1}^{2} / \omega_{x}^{2}}{\bar{e}_{y}}, \quad \bar{\beta}_{1}=\frac{\varphi_{11}}{\varphi_{11}^{2}+\varphi_{21}^{2}}
$$

式(E2a)，(E3a)より、等価剛床モデルの $\bar{\phi}_{21} / \bar{\phi}_{11}$ は、非剛床モデルの $\left(\phi_{21}+\phi_{31}\right) / \phi_{11}$ に等しくなり、両モデルにおける $x$ 方向の壁の変形モードは相似 となる。また、式(E2b), (E3b)から分かるように $\alpha=1$ のときのみ、両モデル の刺激係数も等しくなる。

（2010年10月10日原稿受理，2011年 2 月18日採用決定） 